\title{
Mcl-1 Inhibitor
}

National Cancer Institute

\section{Source}

National Cancer Institute. Mcl-1 Inhibitor. NCI Thesaurus. Code C137990.

Any agent that inhibits $\mathrm{Mcl}-1$. 